\title{
NYILVÁNOSSÁG A BÜNTETŐELJÁRÁSBAN: A JÁRVÁNYHELYZET EGY ÚJABB KÉRDÉSES PONTJA
}

\section{Szerző:}

Németh János

Debreceni Egyetem

Szerző e-mail címe:

nemeth.janos97@gmail.com
Lektorok:

Prof. Dr. Elek Balázs

Debreceni Egyetem

Dr. Sipos Ferenc

Debreceni Egyetem

és további két anonim lektor...

\section{Absztrakt}

A COVID-19 járványhelyzet új kihívások elé állította a világ igazságszolgáltatási rendszereit. Jelentősen elterjedtek a távmeghallgatások a büntetőeljárásokban, és számos példa található az on-line bíróságok felé mutató gyakorlatra. A magyar jogalkalmazásban hangsúlyos szerephez jutnak a távmeghallgatások, de a jelenlegi körülmények között ugyancsak fontos szempont a tárgyalások nyilvánosságának biztosítása is.

Kulcsszavak: büntetőeljárás, nyilvánosság, igazságszolgáltatás, távmeghallgatás

Diszciplina: jogtudomány

\section{Abstract}

PUBLICITY IN CRIMINAL PROCEDURE:

AN OTHER PROBLEMATIC POINT OF THE PANDEMIC

The COVID-19 pandemic challenged the whole world's judicial systems. The use of remote hearings spread significantly in criminal proceedings, and there are also many examples hinting towards on-line courts. Remote hearings are a relevant part of the hungarian judicial system, but under the present circumstances, publicity of the trials is and important aspect as well.

Keywords: criminal procedure, publicity, jurisdiction, remote hearing

Discipline: jurisprudence

Németh János (2021): Nyilvánosság a büntetőeljárásban: a járványhelyzet egy újabb kérdéses pontja. Mesterséges intelligencia - interdiszciplináris folyóirat, III. évf. 2021/1. szám. 61-70. doi: 10.35406/MI.2021.1.61 
A 2020. tavaszán kihirdetett veszélyhelyzet során elrendelt szabályok nagy mértékben kihatottak a büntetőbíróság előtti távmeghallgatások alkalmazására. Ezek a változtatások olyan elméleti és gyakorlati kérdéseket is felvetettek, amelyek eddig is kérdésesek voltak a jogintézmény alkalmazása kapcsán: ilyenek voltak különösen a távmeghallgatás és a közvetlenség elvének kapcsolata, a tárgyalás pszichológiai tényezőinek változásai és az új eszközök alkalmazásához való hozzáállás az eljárásokban.

A távmeghallgatással kapcsolatos jogszabályi változások vizsgálata alapján is elmondható, hogy ezen technológiai újítás egyre széleskörűbb és gyakoribb alkalmazása kétségtelenül komoly - akár a digitalizációval, on-line bírósági eljárásokkal kapcsolatos - változások, s így a közvetlenséghez hasonlóan egyéb elvek újraértelmezésének előfutára is lehet a büntetőeljárásokban. Az ilyen jellegû további - pozitív - változások elősegítéséhez azonban az eddigi tapasztalatok, valamint a gyakorlat vizsgálata szükséges. Ezzel kapcsolatban pedig - s egyébként a büntetőeljárás egészére - igaznak vélem Richard Susskindnak (2020) az online ítélkezéssel és az esküdtszékekkel kapcsolatos véleményét: „elsősorban nem a technikát kell idomítani a megszokott eljárásrendhez, hanem inkább egyet hátra kell lépni, és megvizsgálni, hogy a megszokott gyakorlat milyen alapvető értékeket és elveket képvisel, milyen gyakorlati eredménye és előnye van, és hogy ezek vajon átültethetőek-, illetve javíthatóak-e új és eltérő eszközökkel egy digitális társadalomban." Véleményem szerint ilyen alapvető elv a közvetlenség mellett a nyílvános tárgyalás elve, melyet a járványhelyzet következtében a hazai jogrendszerben - a közvetlenséghez hasonlóan - új szabályok, a külföldi gyakorlatban pedig megfontolandó technikai megoldások helyeztek új megvilágításba. E tanulmány éppen ezért a magyar büntetőeljárásban érvényesülő nyilvánosságra vonatkozó törvényi szabályozás után a járványhelyzet hatására bekövetkezett változtatásokat ismerteti, s fogalmaz meg a hazai és külföldi megoldásokkal kapcsolatos gondolatokat, melyek a büntetőeljárás jövőjére tekintettel is relevánsak lehetnek.

\section{A büntetőeljárások nyilvánosságáról}

Magyarország Alaptörvénye (a továbbiakban: Alaptörvény) kimondja, hogy „,mindenkinek joga van ahhoz, hogy az ellene emelt bármely vádat vagy valamely perben a jogait és kötelezettségeit törvény által felállított, független és pártatlan bíróság tisztességes és nyilvános tárgyaláson, észszerű határidőn belül bírálja el" (XXVIII. cikk (1) bekezdés). A tárgyalás nyilvánosságának igénye tehát olyan alapvető követelménye a bíróság előtti eljárásoknak, melyet az Alaptörvény is szorosan együtt kezel a tisztességes eljárással, s így a büntetőeljárásokban is értelemszerűen érvényesülnie kell. A nyilvánosság már az 1840-es évek óta alapelve a bírósági eljárási szaknak (Antal, 2010), s a büntetőeljárásról szóló 2017. évi XC. törvény (a további- 
akban: Be.) a bíróság tárgyalását szintén nyilvános eljárási cselekményként aposztrofálja. Németh $(2019,58$ o. orávilágít arra, hogy „a nyilvánosság elsődlegesen a büntetőeljárás tárgyalási szakaszához köthető processzuális alapelv". Megfogalmazásában az ,a terhelt és az állam viszonyát szabályozza és elsődleges védelmet jelent a bírói önkény ellen, valamint tágabb értelemben garanciát nyújt a tisztességes eljárás megvalósulásának azzal, hogy biztosítja a büntetőeljárás átláthatóságát."

A büntetőeljárás meghatározott szakaszaiban lefolytatható egyéb eljárási cselekmények (így például a tanácsülés vagy a nyilvános ülés), valamint az eljárás különböző szakaszai (így például a nyomozati szak) más megítélés alá esnek. Egyébként pedig a bíróság előtti eljárási cselekmények esetében sem érvényesül kivétel nélkül a nyilvánosság: maga a Be. - annak 436-437. $\S$-aiban - is meghatároz olyan körülményeket, eseteket, amikor a jelenlevők létszámának, személyének korlátozására, esetleg a nyilvánosság teljes kizárására kerülhet sor: alapvető kikötés, hogy a tárgyaláson hallgatóként tizennegyedik életévét be nem töltött személy nem vehet részt, de az eljáró bíró a tizennyolcadik életévét be nem töltött személyt is kizárhatja a hallgatóság köréből, egyébként pedig meghatározhatja a hallgatóság létszámát a tárgyalás szabályszerû lefolytatása, méltóságának és biztonságának megőrzése érdekében, illetve helyszűke esetén. Hivatalból vagy indítványra teljeskörūen kizárhatja a nyilvánosságot az egész tárgyalásról vagy annak egy részéről, s ezzel együtt erkölcsi okból - jellemzően a nemi élet szabadsága és a nemi erkölcs elleni bűncselekmények esetén -, különleges bánásmódot igénylő személy védelme érdekében - például tanúvédelmi okból -, illetve minősített adat és egyéb védett adat - például üzleti titok - védelme érdekében zárt tárgyalást rendelhet el. Tanúvédelmi szempontból a tárgyaláson jelenlevők személyének meghatározása lényeges eszköz, a nyilvánosság, mint alkotmányos garancia pedig nem szolgálhat joggal való visszaélés alapjául, és nem lehet akadályozója annak, hogy a tanúk eleget tehessenek igazmondási kötelezettségüknek (Kúria Bfv.1200/ 2016/6.). Ilyen esetben figyelmezteti a jelenlévőket arra, hogy a tárgyaláson elhangzottakról tájékoztatást nem adhatnak, szükség esetén pedig a minősített adattal visszaélés büntetőjogi következményeire is. Fontos azonban, hogy a bíróság a zárt tárgyalás elrendelése esetén is engedélyezheti, hogy az igazságszolgáltatással összefüggő feladatokat ellátó hivatalos személyek a tárgyaláson jelen legyenek, külföldi állampolgár vádlott ellen, illetve a külföldi állampolgár sértett sérelmére elkövetett bűncselekmény miatt indult eljárás során pedig lehetővé kell tenni, hogy a tárgyaláson annak saját államának konzuli tisztviselője, illetve törvénnyel kihirdetett nemzetközi szerződés rendelkezése alapján a külföldi állam hatóságának tagja jelen lehessen. A minősített adat védelme érdekében történő elrendelés kivételével zárt tárgyalás elrendelése esetén a sértett, ha nincs képviselője, illetve a vádlott, ha nincs védője, indítványozhatja, hogy a tárgyalás 
helyszínén tartózkodó, általa megnevezett személy - ide nem értve a tárgyaláson kihallgatandó személyt - jelen legyen a tárgyaláson. Lényeges garanciális szabály továbbá, hogy a tárgyalást nyilvánosan kell folytatni, ha a zárt tárgyalás indoka megszűnt.

A nyilvánosság biztosításához szorosan kapcsolódik a tárgyalás rendjének és az eljárás méltóságának megőrzése is: az eljáró bíró - az egyesbíró vagy a tanács elnöke - a Be. 440. § (1)-(2) bekezdései alapján rendre utasítja és rendbírsággal sújthatja azt, aki a tárgyalás rendjét vagy szabályszerű menetét zavarja, ismételt vagy súlyos rendzavarás esetén pedig a rendzavarót kiutasíthatja, illetve kivezettetheti a tárgyalásról, valamint ,abban az esetben, ha a rendzavarás a hallgatóság körében merül fel, a bíróság az egész hallgatóságot kizárhatja anélkül, hogy vizsgálná, személy szerint ki és kik voltak azok, akik ismételten vagy súlyosan megzavarták a tárgyalás rendjét. Ebben az esetben nem zárt tárgyalást rendel el a bíróság, ilyen okra alapítottan nincs is helye a zárt tárgyalás elrendelésének. Előfordulhat azonban, hogy a különleges bánásmódot igénylő személy védelme érdekében azt követően dönt a zárt tárgyalásról, hogy a hallgatóság rendzavaró módon félemlíti meg az ilyen védettséget élvező eljárási szereplőt" (Elek, 2020). A Be. 439. § (3) bekezdése alapján az eljáró bíró gondoskodik a tárgyalás méltóságának megőrzéséről, s ennek érdekében köteles a tárgyalóteremből eltávolíttatni azokat, akik a tárgyalás méltóságát sértik. Ez azért is lényeges, mert - amint arra Elek (2020) rámutat -, a tárgyalás rendjének fentebb is ismertetett megsértése minden esetben sérti a tárgyalás méltóságát is, de ez utóbbit olyan magatartás is megvalósíthatja, amely egyébként nem minősül rendzavarásának, s így a rendzavarás következményeit sem lehet alkalmazni. Ezzel kapcsolatban kiemeli azt is, hogy „a tárgyalás méltóságának megsértésére alapított tárgyalásvezetési jogkör elsősorban a hallgatóságra vonatkozik, de alkalmazható tágabb körben, így a sajtó munkatársaira is. A tanács elnöke jogosult eldönteni, hogy milyen magatartás, viselkedés vagy megjelenés (például nem tárgyalóterembe illő öltözék) sérti a tárgyalás méltóságát” (Elek, 2020). Az eljárást vezető egyesbíró vagy tanácselnök számára tehát több lehetőség is kínálkozik a rendzavaró, az eljárás méltóságát sértő személlyel szemben, s nem jelent ezek alól mentesülést az sem, ha az a hallgatóság tagjaként, a nyilvánosság elvét érvényre juttatva van jelen az eljárási cselekmény helyszínén.

\section{A járványhelyzetben}

\section{bekövetkezett változások}

Jelen körülmények között a fent ismertetett, az eljárásban résztvevő személyének biztonságára, az eljárás rendjére és méltóságára vonatkozó igények mellett egy másik fontos szempont is előtérbe került: fokozott hangsúlyt kapott ugyanis a tárgyalótermek befogadóképességének és a tárgyaláson jelenlévő személyeknek, a hallgatóság létszámának, kérdése is, tekintettel a 
COVID-19 járvány elleni védekezésre. A jogalkotó a távolságtartás igényén túl megfogalmazott további megelőző rendelkezéseket is, melyek a büntetőeljárások nyílvánosságát is érintik. Ezeket a jelenleg hatályban lévő, a veszélyhelyzet megszűnésével összefüggő átmeneti szabályokról és a járványügyi készültségről szóló 2020. évi LVIII. törvény (a továbbiakban: Vmtv.) 204-205. §-ában szabályozza. Előbbiben kimondja, hogy hivatalból vagy indítványra meghatározhatja a bíróság a hallgatóság létszámát járványügyi intézkedés megtartása érdekében vagy egészségügyi válsághelyzettel összefüggő más okra figyelemmel. Ez tehát már kétségkívül magában foglalja a terem befogadóképességére vonatkozó létszámkorlátozást. A 205. § a nyilvánosság kizárásának lehetőségét tágítja ki azzal, hogy kimondja, a bíróság hivatalból kizárja a nyilvánosságot a tárgyalásról (vagy annak egy meghatározott részéről), amennyiben járványügyi intézkedésre vagy az egészségügyi válsághelyzettel összefüggő más rendelkezésre figyelemmel a bíróság a nyílvánosság számára nem látogatható. Amennyiben tehát járványügyi rendelkezésre tekintettel az adott bíróság épületébe csak meghatározott személyek léphetnek be, úgy célszerűen a hallgatóság sem vehet részt eljárási cselekményeken, mivel így értelmét vesztené a megelőző-védekező intézkedés is.

A Vmtv. 205. § (3) bekezdése alapján - a nyilvánosság érvényre juttatásának érdekében - ilyenkor a terhelt vagy a védő indítványára engedélyezni kell, hogy azok a náluk levő elektronikus eszközt bekapcsolva a tárgyaláson történteket rögzítsék. A bíróság a rögzítés engedélyezésekor figyelmezteti a terheltet a személyes adatok kezelésével összefüggő kötelezettségeire. A Vmtv. kimondja, hogy rögzítés nem engedélyezhető, ha a tárgyalásról a bíróság készít kép- és hangfelvételt, vagy a zárt tárgyalás elrendelésének törvényben meghatározott egyéb - akár a fentebb meghatározott bármely - okból van helye. A bíróság által készített kép- és hangfelvétel másolatát a tárgyalást követő nyolc napon belül az indítványt előterjesztő terhelt és a védő részére meg kell küldeni, vagy azt részükre hozzáférhetővé kell tenni. Fontos követelmény továbbá, hogy - összhangban a ténylegesen jelenlévő hallgatóságra vonatkozó szabályokkal - az eljáráson történtek ilyetén rögzítése nem járhat a tárgyalás rendjének, szabályszerű menetének zavarásával vagy a tárgyalás méltóságának sérelmével. Ilyen esetben ugyanis a bíróság megtiltja a rögzítés folytatását és a rendzavarás - ugyancsak fentebb hivatkozott következményeit alkalmazza. A jogalkotó továbbá rögzíti, hogy nem büntethető a Büntető Törvénykönyvrôl szóló 2012. évi C. törvény (a továbbiakban: Btk.) 280. §ának (2) bekezdésében szabályozott igazságszolgáltatással összefüggő titoksértés miatt az, aki az ilyen módon elrendelt zárt tárgyaláson elhangzottakat felfedi.

A jogalkotó által alkalmazott megoldás a gyakorlatban könnyedén megvalósítható, és valóban lehetőséget biztosít - akár sokkal szélesebb - nyilvánosság biztosításának, hiszen az így rögzített felvétel az inter- 
neten keresztül jelentősen nagyobb számú állampolgárhoz juthat el, mint amit egy tárgyalóterem befogadóképessége akár normális körülmények között is lehetővé tenne. Megfontolandó azonban az az eshetőség, hogy amint azt egy, a Pesti Központi Kerületi Bíróság előtt - a jelen tanulmány megírásának idejében - folyamatban lévő becsületsértés vétségének ügyében (B. 20773/2020) is történt, a járványügyi veszélyhelyzet miatt kizárt nyílvánosság okán rögzített tárgyalás akár olyan közismert médiatartalom-megosztó oldalakra (jelen esetben ez a YouTube) is felkerülhet, amit nap mint nap emberek milliói láthatnak. Kérdésessé válik ugyanis, hogy mennyire felel meg a nyilvánosság követelményének például egy, a szerkesztéshez, videóvágáshoz értő személy által saját szájíze szerint megvágott, s csak ezután közzétett felvétel. Nem is gondolva arra, hogy a közzétevő így esetleg valóban lényegi mozzanatokat, elhangzott részleteket hagy ki az eljárási cselekményből, úgy vélem, már magának a tárgyalás menetének, valósághű lefolyásának a megtörése is káros lehet. Amíg ugyanis lehetséges, hogy a hétköznapi ember egy vágatlan felvételt nem tekint vagy hallgat meg teljes egészében, hanem csak az ôt érdeklő részekhez „léptet”, még mindig megvan a lehetősége, hogy ha akar, minden mozzanatot figyelemmel kísérjen. Célszerűnek tartanám ezért, hogy egyértelmű jogszabályi követelmény legyen arra nézve, hogy a tárgyaláson rögzítetteket ilyenkor teljes egészükben nyilvánosságra kelljen bocsátani, s így a „hallgatóságra” bízni, hogy abból mire kíván valóban nagyobb figyelmet fordítani.

Az új szabályok elsősorban a nyilvánosság érvényesülésének korlátozásában figyelhetők meg, amit a fokozott járványügyi védekezés indokolt. A jogalkotó az ilyen okból kizárt nyilvánosságot az eljárási cselekményen optimális esetben résztvevő terhelt, illetve a védő kérelmére engedélyezett rögzítéssel igyekszik pótolni. Ez alól kivétel, ha az eljárási cselekmény egyébként is rögzítésre kerül, melynek tökéletes példája lehet egy távmeghallgatással tartott tárgyalás, ugyanis a Be. 125. § (2) bekezdése alapján - amennyiben jogszabály kivételt nem tesz - a telekommunikációs eszközzel továbbított felvételt mindig rögzíteni kell. Az eljárások folyamatos rögzítése, a tárgyalásokról készült felvétel nyilvánosan elérhetővé tétele kívánatos - s egyben a jelenlévő hallgatóságot szinte a legmegfelelőbben helyettesítő megoldásnak tủnhet, gondolva akár csak arra, hogy a nyilvánosságnak sokkal szélesebb körét érheti el, s még az a veszély sem fenyeget, hogy az eljárási cselekmény rendje, méltósága közvetlenül sérüljön. Ennél pedig már csak az élőben közvetített tárgyalások tűnhetnek ,jobb” megoldásnak. Habár a Vmtv. - a terhelt és a védô általi rögzítéssel kapcsolatban - már egyértelműen kiterjeszti azt a szabályozást, amit „a jogalkotó a klasszikus értelemben, kameraállványokkal és mikrofonokkal megjelenő sajtóorgánumok tárgyalóteremben való jelenlétére alkot" (Németh, 2019, 59. o.), továbbra is fennáll a kérdés, hogy „vajon a jogalkotó szándéka kiterjesztően 
értelmezve, magában foglalja a tárgyalásokon megvalósuló élő közvetítéseket is?" (Németh, 2019, U.o.) Véleményem szerint ilyen törekvésre egyelőre nem található utalás. A nyilvánosságnak ilyen mértékű kiterjesztése egyértelmű szabályozást igényel, mivel az nemcsak technikai, de alapjogi problémákat is magában hordoz: akár a terhelt, akár a védő, de akár csak a bíróság által rögzített felvétel élőben, on-line történő közvetítése esetén különös figyelmet kell szentelni azokra, akik megtagadhatják, hogy róluk felvétel készüljön. Ilyen tekintetben tehát gyakorlatilag visszatérünk a nyilvánosság korlátozására vonatkozó, az első fejezetben is ismertetett szabályokhoz: ugyanúgy érvényesülnie kell ugyanis a tanúvédelemre, erkölcsi szabályokra vagy titokvédelemre vonatkozó követelményeknek, különös tekintettel arra, hogy az interneten közvetített felvételt szinte bárki képes lehet rögzíteni, s a képernyő- vagy hangfelvételekkel, képernyőképekkel később visszaélni. Éppen ezért az esetleges on-line streaming megvalósításához átfogó, kógens szabályozásra lenne szükség mind annak technikai megvalósítását illetően, mind az eljárásban résztvevő személyek vonatkozásában, hiszen, amint egy rendkívül gyakorlatias példában Németh (2019, 60. o.) is rámutat, adott esetben a bíróság folyosóján várakozó, kihallgatás előtt álló tanú is használhatná a saját mobiltelefonját, vagy más elektronikus eszközét, s ezen nyomon követhetné akár az ajtó túloldalán folyamatban lévő tárgyalásról szóló élő közvetítést is.

\section{Kanadai és amerikai megoldások}

A tárgyaláson történtek rögzítése és közzététele a médiaszolgáltatók közvetítése útján - a nyilvánoság tájékoztatására vonatkozó szabályokra is figyelemmel eddig is megvalósulhatott, a vádlott vagy védője általi rögzítés mégis új megoldás, s nem szorítkozik csak olyan esetekre, amit előbbiek is hírértékűnek minősítenek. Az azonban kétségtelen, hogy a valós időben jelenlevő nyilvánosságot ez sem képes pótolni. A kérdés így az lehet, hogy van-e más reális megoldási lehetőség? A nemzetközi gyakorlatot figyelembe véve erre a kérdésre igenlő válasz adható: a nyilvánosság digitális biztosítására (távmeghallgatás igénybevételével tartott eljárási cselekmények esetén) ugyanis egyre több külföldi példa áll rendelkezésére.

Schmitz (2020) beszámol arról, hogy távmeghallgatással tartott tárgyalásokat a nyílvánosság számára online közvetítenek a kanadai Legfelsőbb Bíróság honlapján, de újításként már a Zoom platformon is nyomon követhetőek az események, ahol - a weboldalon közvetített adással ellentétben - nem csak a beszélőt látja a néző, hanem az szabadon váltogathatja a kameraképet, így akár egy-egy kiválasztott, de akár minden az eljárásban résztvevő személyt egyszerre is figyelhet. Egyébként az eljárás résztvevői is a Zoom platformot használják, azzal a különbséggel, hogy - értelemszerűen - a hallgatósággal ellentétben nekik a mikrofon- és kamerafunkciók is rendelkezésükre állnak.

Washington állam bíróságai külön honlapon biztosítanak lehetőséget az egyébként 
ugyanott élőben közvetített virtuálisan zajló eljárási cselekmények utólagos megtekintésére is. A későbbi megtekintéshez, az elhangzottak nyomon követéséhez segítséget nyújt a videók alatt megtalálható (automatikusan, számítógép által generált) szövegátirat, mely az írásban így rögzített felszólalások kezdetét időbélyegzővel jelöli, s így segíti a visszakereshetőséget. Ilyen, visszanézhető bíróság előtti eljárásokra példa a tavaly októberben a State of Washington v. Cory Pratt (Net2), novemberben a State of Washington v. Tanner Lee Coryell (Net3), vagy az idén január 21én, a State of Washington v. Lynell Avery Denham (Net1) ügyben lefolytatott eljárási cselekmények.

\section{Konklúziók}

A távmeghallgatásokkal kapcsolatos külföldi joggyakorlat és a hazai szabályozás vizsgálata a technológiai újításokkal kapcsolatban egy másik alapvető követelmény, a nyilvánosság érvényesülésének új kérdéseire mutatott rá. „A nyilvánosság elve, mint a büntetőeljárás általános processzuális alapelve, garanciát jelent az eljárási résztvevők számára, hogy a bíróság pártatlanul és függetlenül járjon el, továbbá az eljárási jogok megfelelő gyakorlása is ellenőrizhetô általa" (Varga, 2018, 90. o.). A nyilvánosság érvényre juttatása eljárásjogi garancia, s így nem az állampolgárok szórakozását hivatott biztosítani. A tárgyalások személyes jelenléten alapuló figyelemmel kísérésének mindenképpen lehetőséget kell biztosítani, de az nem szolgálhat az eljárások rendezett és méltóságteljes lefolytatásának akadályául. Éppen ezért a bíróságnak jogot kell biztosítani arra, hogy a tárgyalás rendjének, méltóságteljes lefolytatásának érdekében korlátozhassa a jelenlévők körét. Ugyancsak nyilvánvaló, hogy egy - a jelenlegihez hasonló - járványhelyzet esetén sem állhat az emberek egészségének, testi épségének védelme elébe a nyilvánosság biztosítása a tárgyaláson, amennyiben az ténylegesen személyes jelenléttel valósul meg. Már pedig a hazai jogrendszerben egyelőre csak a személyesen megjelenő hallgatóság követheti nyomon valós időben a tárgyalóteremben történteket. Az ott történtek közvetítésével, rögzítésével kapcsolatban „A jogalkotó a klasszikus értelemben, kameraállványokkal és mikrofonokkal megjelenő sajtóorgánumok tárgyalóteremben való jelenlétére alkot szabályokat." (Németh, 2019, 59. o.). A jelenlegi helyzetben pedig éppen ezért még aktuálisabb a kérdés, hogy „,vajon milyen rendelkezéseket kell alkalmazni abban az esetben, ha valamely sajtószerv képviselője, vagy akár bármelyik magánszemély a mobiltelefonjával, a tárgyalással egy időben, élő-közvetítés (online-streaming) formájában tájékoztatja a társadalom szélesebb körét a büntetőeljárás menetéről?" (Németh, 2019, u. o.). Ugyancsak hangsúlyosnak tartom a felvett anyag későbbi közzétételének mikéntjére vonatkozó átfogó szabályanyag kidolgozását, így a) - amint arra a 2. fejezetben is utaltam -, akár arra nézve írni elő kötelezettséget, hogy az eljárási cselekményen rögzítetteket - természetesen minden 
más eljárási garanciának megfelelően - teljes egészükben, vágatlanul legyen köteles a közzétevő nyilvánosságra hozni, vagy akár b) egységesen, a bíróság általi rögzítést biztosítani, s az így felvett anyagot erre rendszeresített felületen - például internetes honlapon - közzétenni, ezzel is garantálva annak valósághű és teljes voltát.

Az nemzetközi példákból jól látható, hogy bizonyos esetekben akár büntetőeljárásokban távmeghallgatás alkalmazásával tartott eljárási cselekmények esetén is lehetséges egyúttal valós időben (de akár későbbi megtekintés lehetőségét biztosítva rögzítve is) a világhálón hozzáférhetővé tenni az ott elhangzottakat, ezzel biztosítva széles körű nyilvánosságot akár olyan ügyekben is, amikor az eljáró bírón - vagy bírói tanács tagjain - kívül más nem is tartózkodik a bíróság épületében. Mindenképpen szükséges lenne azonban a részletekre kiterjedően szabályozni egy hasonló rendszer alkalmazását abban az esetben, ha azt ténylegesen igénybe kívánná venni a hazai jogalkalmazás. Nem kívánatos ugyanis, hogy elsietett félmegoldások akár alapvető jogok tömeges sérelmét eredményezzék.

Susskind (2020) szerint a bíróságoknak is gondolkodásmódbeli változásra van szükségük ahhoz, hogy a járványhelyzet miatt bekövetkezett újításokat megfelelően tudják kezelni. Az eddigiekben bekövetkezett változtatások szerinte azonban nem az átalakulást - a rendes bírósági eljárásoknak az online bíróságokká történő fejlődését vetítik előre, hanem szimplán automatizációt sejtetnek, a jelenlegi ítélkezési rendszernek a Zoom platformra történô „behajítása” pedig nem tekinthető tényleges paradigmaváltásnak. A nemzetközi gyakorlatban alkalmazott megoldásokat megfontolandónak tartom, nem feledkezve meg arról, hogy büntetőeljárások esetében fokozott figyelmet kell fordítani más eljárásjogi garanciáknak, az eljárásban részt vevő személyek alapvető jogainak, testi épségének védelmére is. Mindemellett úgy vélem, a távmeghallgatások egyre gyakoribb alkalmazása során az ilyen módon megvalósított eljárási cselekményeken a nyílvánosság biztosítására vonatkozó külföldi gyakorlat akár a hazai jogalkotásra is hatással lehet, mely a jelenlegi helyzetben, de a jövőben is, nagyban hozzájárulhatna az eljárások nyugodt körülmények között zajló, s mégis valós időben történő figyelemmel kíséréséhez. Ha ez így történne, kétségkívül egy hatalmas lépéssel közelebb kerülnénk az on-line bírósági eljárások megvalósulásához, még ha ez számos további elméleti és gyakorlati kérdést is vetne fel.

\section{Irodalom}

2017. évi XC. törvény a büntetóeljárásról 2017. évi XC. törvény Miniszteri Indokolása Antal, D. (2010). A nyilvánosság és a büntetőeljárás. Studia iuvenum iurisperitorum, 2010/5, 219-239.

Elek, B. (2020). A Be. 439-440. 』-ához in.: Polt Péter (szerk.) (2020) Kommentár a büntetöeljárásról szóló 2017. évi XC. törvényhez, Wolters Kluwer Hungary Kft., Budapest, On-line elérhető változat Web: 
https://uj.jogtar.hu/\#doc/db/396/id /A17Y0090.KK/ts/20200701/lr/chai n6699/ (megtekintve: 2020. 02. 10., A kommentár utolsó időállapota: 2020. július 1.)

Kúria Bfu.1200/2016/6.

Magyarország Alaptörvénye

Németh, K (2019). A büntetőeljárás nyilvánosságának jogszabályi hátterében húzódó alapjogi kollíziók feltárása, különös tekintettel az ágazati titokvédelemre. Debreceni Jogi Mühely (XVI. évfolyam) 2019/1-2, 55-76. DOI 10.24169/DJM/2019/1-2/5

Net1: State of Washington v. Lynell Avery Denham, Washington State Supreme Court, January 21, 9:00 am, Web: https://www.tvw.org/watch/?clientI $\mathrm{D}=9375922947$ \&eventID $=202101124$ 8\&autoStartStream $=$ true (megtekintve: 2020. február 3.)

Net2: State of Washington v. Cory Pratt, Washington State Supreme Court, Oct. 20, 2020 - 10:00 am Web: https://www.tvw.org/watch/?clientI $\mathrm{D}=9375922947$ \&eventID $=202010111$
2\&autoStartStream $=$ true (megtekintve: 2020. február 3.) Net3: State of Washington v. Tanner Lee Coryell, Washington State Supreme Court, Nov. 10, 2020 - 1:30 pm, Web: https://www.tvw.org/watch/?clientI $\mathrm{D}=9375922947$ \&eventID=202011104 2\&autoStartStream $=$ true (megtekintve: 2020. február 3.)

Schmitz, C. (2020). SCC poised for first virtual appeal hearing; Zoom 'observers' to see novel contract, criminal cases Web: https://www.thelawyersdaily.ca/articl es/19410/scc-poised-for-first-virtualappeal-hearing-zoom-observers-tosee-novel-contract-criminalcases? category $=$ news (megtekintve: 2020. október 23.)

Susskind, R. (2020). The Future of Courts, The Practice, 2020/5

Varga, P. (2018). A nyilvánosság elvének érvényesülése a büntetőeljárásban, Debreceni Jogi Mühely (XV. évfolyam) 2018/ 1-2. 76-92. o. DOI 10.24169/DJM/2018/1-2/9 